\title{
Non-antimicrobial effect of Alocasia denudata Engler against selected Gram-positive oral pathogen
}

\author{
Nurul Akilah Mohd Yusoff, Tuan Nadrah Naim Ismail, Wan Nazatul Shima Shahidan*
}

School of Dental Sciences, Universiti Sains Malaysia, 16150 Kubang Kerian, Kelantan, Malaysia

\begin{abstract}
Introduction: Alocasia denudata is a herbal plant used by traditional healers as a wound healing agent and its potential as a healer has been proven scientifically. Normally, wounded tissue offers the opportunity for microflora to adhere, colonize, invade, and infect the surrounding healthy tissue. Therefore, the aim of this study is to assess the antimicrobial effect of $A$. denudata on selective oral pathogen as well as to analyze its phytochemical compound.

Methods: The stem of $A$. denudata was extracted with $80 \%$ ethanol solution, freeze-dried, and sent to poison center to analyze its phytochemical constituents. The bioassay applied for determining the antimicrobial effect employs the well agar diffusion method to the selected Gram-positive oral bacteria; Streptococcus mutans, Staphylococcus aureus, Enterococcus faecalis, and non-oral pathogen Streptococcus pyogenes. These bacteria were incubated and the inhibition zone was recorded.

Results: Our results showed that the mean yield of extraction was $12.8 \%$ and that the different concentrations of $A$. denudata show no antimicrobial effects toward the selected Gram-positive oral pathogen including non-oral pathogen bacteria. However, the gas chromatography-mass spectrometry result showed that antimicrobial compound is present along with anti-inflammatory and antioxidant compounds but showed no effect on the oral pathogen.
\end{abstract}

Conclusion: $A$. denudata extract has antimicrobial compound but did not show antimicrobial activity toward the selected Gram-positive oral pathogen.

Keywords: Alocasia denudata extract; antimicrobial; Gram-positive oral pathogen; gas chromatographymass spectrometry

\section{INTRODUCTION}

Alocasia denudata is a tropical plant that belongs to the Alocasia genus. Alocasia spp. usually growing in its original area and mostly used as an ornamental

\footnotetext{
*Corresponding author: Dr. Wan Nazatul Shima Shahidan, Oral Biology Unit, School of Dental Sciences, Universiti Sains Malaysia, 16150 Kubang Kerian, Kelantan, Malaysia. Tel: +6097675806. Fax: +609767 5505. E-mail: shima@usm.my
}

Submitted: 03 November 2019/Accepted: 19 March 2020 purpose. Its traditional name is "keladi canek" or "keladi candik" (1). Various studies have reported the medicinal property of Alocasia spp., especially for antioxidant, antitumor, antimicrobial, antidiabetic, anticancer, and antihyperlipidemic (2-5). $A$. denudata is widely used as a traditional medicine to treat external skin wounds (6). Abdul Latif et al. have scientifically proven that $A$. denudata stem juice can accelerate the wound healing process (7).

Recently, many scientific types of research had been carried out from common domestic herbs that had 
been traditionally used to treat oral diseases such as ulcers, toothache, and gum disease (8). Moreover, many types of research, nowadays, had been carried out to develop an effective antimicrobial agent toward the oral pathogen. Furthermore, the usage of modern technology such as involvement of pesticide in agricultural contributing to the production of antimicrobial agent that has some limitation in terms of bacterial resistance (9). As an increasing number and frequency usage of the antibiotic, the resistance of infectious beings toward the antibiotics will be increased too (10). Antibiotics can be found in many forms, which are the products of microorganisms, medicinal plants, and complex organisms. There will be possible chances to develop new drugs for therapeutic purposes if the toxic effect after the application of this medicinal plant extract is minimal (11). The plant usually synthesizes secondary metabolites, which show antimicrobial effect and this type of plant can be used for synthesizing new drugs (12). Many of the traditional medicinal plants used are scientifically proven through research by isolating bioactive compounds for direct use in medicine. Past published reports on $A$. denudata have very limited information made available in terms of its antimicrobial activity and chemical constituents. Realizing the potential antimicrobial of this species, we performed a study to test its antimicrobial activity against the selected Gram-positive oral pathogen and determined its phytochemical compound.

\section{METHODS}

\section{Plant material and sample collection}

The stem of $A$. denudata was collected and determined based on the previous studies (7). In general, the stems were washed thoroughly and cut into smaller pieces of $3 \mathrm{~cm}$ in length. The cut sample was rinsed and allowed to dry in the oven at $50^{\circ} \mathrm{C}$ for 5 days. The dried stem was powdered using an electric blending machine (Panasonic) and kept at $4^{\circ} \mathrm{C}$ in a tight capped $15 \mathrm{ml}$ Falcon Conical Centrifuge tubes.

\section{Preparation of plant extract}

The extract preparation involved the use of ethanol as a solvent for extraction preparation. The gravity filtration technique was used to extract the crude compound of $A$. denudata. Twelve grams of the specimen were dissolved in $40 \mathrm{ml}$ of $80 \%$ ethanol. This solution afterward was left on a reciprocating shaker (reciprocating shaker SSL2) which was set to have 200 strokes per min for 2 days. The mixture was then centrifuged briefly at 25,000 rpm for 5 minutes using Biofuge primo general centrifuge. The mixture was filtrated with Whatman filter paper No. $1(110 \mathrm{~mm})$ and transferred into a falcon tube. Next, the solvent was removed using a rotary evaporator (Concentrator plus Eppendorf V-AL) yielding the extracted compound and was subjected for freeze-drying using ScanVac CoolSafe Freeze Dryer to obtain the plant extract in a powder form. The dry powder of extract was kept in a $15 \mathrm{ml}$ Falcon tube at $-20^{\circ} \mathrm{C}$ until further use. The extract was weighed and dissolved in sterile distilled water to make a final concentration of $16 \mathrm{mg} / \mathrm{ml}, 8 \mathrm{mg} / \mathrm{ml}$, $4 \mathrm{mg} / \mathrm{ml}$, and $2 \mathrm{mg} / \mathrm{ml}$.

\section{Determination of extraction yield}

The yield $\left(\%, \mathrm{w}_{1} / \mathrm{w}_{2}\right)$ from the extract was calculated using the following equation:

Yield $(\%)=\frac{\mathrm{w}_{1}}{\mathrm{w}_{2}} \times 100$, where, $\mathrm{w} 1$ is the weight of extract residue obtained after solvent removal and $\mathrm{w}_{2}$ is the weight of the plant stem.

\section{Bacterial strain}

The bacterial strain used in this study was obtained from the Medical Microbiology and Parasitology Laboratory, School of Medical Sciences, Universiti Sains Malaysia, comprising Gram-positive bacteria, Staphylococcus aureus, Streptococcus mutans, Enterococcus faecalis, and Streptococcus pyogenes. All these bacteria strains were grown and maintained on sheep blood agar and Mueller-Hilton agar for $S$. pyogenes. All agar plates were incubated for 24 hours at $37^{\circ} \mathrm{C}$ and maintained at $4^{\circ} \mathrm{C}$.

\section{Antibacterial assay}

Agar well diffusion methods on sheep blood agar were used qualitatively (13). The in vitro antibacterial activity was assessed for ethanolic extracts of $A$. denudata. Bacterial colonies from the plates were suspended into sterile Mueller-Hinton broth to form turbidity of $0.5 \mathrm{McF}$ arland standard using the DEN-1-McFarland Densitometer. Bacterial 
suspension with approximately $\times 1 \mathrm{CFU} / \mathrm{ml}$ suspension was streaked onto blood sheep agar plates using a sterile swab stick. Subsequently, the wells of $6 \mathrm{~mm}$ diameter each were punched into the agar medium and filled with $100 \mu \mathrm{l}$ of different concentrations of plant extract, positive and negative control under sterile condition. The solutions were allowed to diffuse into the agar for 5 minutes. Ampicillin was used as positive control while distilled water as negative control. The ampicillin concentration used was $20 \mu \mathrm{g} / \mathrm{ml}$ for S. mutans, E. faecalis, and S. pyogenes whereas $500 \mu \mathrm{g} / \mathrm{ml}$ for $S$. aureus due to its resistance. The plates cultured with $S$. aureus, E. faecalis, and $S$. pyogenes were incubated in the incubator for 24 hours, whereas S. mutans was packed in Anaerogen pack and incubated for 48 hours. The triplicate process was carried out for each concentration against each test organism. Microbial growth was determined by measuring the diameter of the inhibition zone in millimeters. An agar well $(6 \mathrm{~mm})$ showing that no zone of inhibition was considered as no antimicrobial activity.

\section{Statistical analysis}

The data were expressed as mean \pm standard deviation.

\section{Gas chromatography-mass spectrometry (GC-MS) analysis}

The powder form of the extract was sent to the National Poison Centre in Pulau Pinang for phytochemical analysis using the GC-MS technique. GC-MS was carried out using Hewlett Packard 6890 GC fitted with 5973N Mass Selective Detector. Helium was used as the carrier gas with a flow rate of $1.0 \mathrm{ml} / \mathrm{min}$ with the oven temperature programmed from $50^{\circ} \mathrm{C}$ (held for 2 minutes) to $280^{\circ} \mathrm{C}$ (held for 10 minutes) at a rate of $10^{\circ} \mathrm{C} / \mathrm{min}$. The injection and interface temperatures were set at $250^{\circ} \mathrm{C}$ and $280^{\circ} \mathrm{C}$, respectively.

One microliter sample was injected in splitless mode and analyzed in MS full scan mode $(\mathrm{m} / \mathrm{z}$ 40-650). The electron ionization was set at $70 \mathrm{eV}$. ChemStation software was used to acquire data. The National Institute of Standards and Technology (NIST) library of mass spectra was used to match and identify the unknown chemical constituents of the mixture.

\section{Identification of the chemical constituents}

The NIST library of mass spectra was used to match and identify an unknown chemical in the sample mixture. The mass spectrum produced by a certain chemical compound is the same every time. Therefore, the mass spectrum is essentially a fingerprint for the molecule. This fingerprint can be used to identify the compound. $A$. denudata compounds were identified by library searching Wiley 275 and NIST 02 mass spectral databases. The percentage compound was calculated from the summation of the peak areas of $A$. denudata compounds.

\section{RESULTS}

\section{The yield of $A$. denudata extract}

The extract yields of three trials of a sample obtained and their respective percentages are presented in Table 1 . The mean, standard deviation, and significant of the extract yield are presented in Table 2.

\section{Agar well diffusion test}

The results of the antimicrobial activity of $A$. denudata are shown in Table 3 . The activity was portrayed by the zones of inhibition for each pathogen that is shown in Figures 1-4. All different concentrations of A. denudata extract displaying zero zone of inhibition indicated that there was no antibacterial activity.

TABLE 1. Yield of the extracts of $A$. denudate

\begin{tabular}{llccc}
\hline Sample & Trial & $\begin{array}{c}\text { Weight } \\
1(\mathrm{~g})\end{array}$ & $\begin{array}{c}\text { Weight 2 } \\
(\mathrm{g})\end{array}$ & $\begin{array}{c}\text { Percentage } \\
\text { of yield }(\%)\end{array}$ \\
\hline A. denudate & I & 1.7 & 12.0 & 14.1 \\
& II & 1.4 & 12.0 & 11.6 \\
& III & 0.7 & 5.5 & 12.7
\end{tabular}

Weight 1 was the weight of the extract after lyophilization/ evaporation of the solvent. Weight 2 was the weight of the plant powder. A. denudate: Alocasia denudate

TABLE 2. Mean and standard deviation of the percentage yield of $A$. denudata extract

\begin{tabular}{lccc}
\hline Variable & $\mathrm{n}$ & Mean & Standard deviation \\
\hline A. denudata extract & 3 & 12.8 & 1.253 \\
\hline A. denudate: Alocasia denudate &
\end{tabular}


TABLE 3. Antimicrobial activity. The diameter of the inhibition zone by the species

\begin{tabular}{|c|c|c|c|c|c|c|c|c|c|c|c|c|c|c|c|c|c|c|}
\hline \multirow[t]{3}{*}{ Organism } & \multicolumn{18}{|c|}{ Diameter of inhibition zone $(\mathrm{mm})$} \\
\hline & \multicolumn{3}{|c|}{$\begin{array}{l}16 \mathrm{mg} / \mu \mathrm{l} \text { of } \\
\text { A. denudata } \\
\text { extract }\end{array}$} & \multicolumn{3}{|c|}{$\begin{array}{l}8 \mathrm{mg} / \mu \mathrm{l} \text { of } \\
\text { A. denudata } \\
\text { extract }\end{array}$} & \multicolumn{3}{|c|}{$\begin{array}{l}4 \mathrm{mg} / \mathrm{\mu l} \text { of } \\
\text { A. denudata } \\
\text { extract }\end{array}$} & \multicolumn{3}{|c|}{$\begin{array}{l}2 \mathrm{mg} / \mathrm{\mu l} \text { of } \\
\text { A. denudata } \\
\text { extract }\end{array}$} & \multicolumn{3}{|c|}{$\begin{array}{l}\text { Positive control } \\
\text { (ampicillin) }\end{array}$} & \multicolumn{3}{|c|}{$\begin{array}{l}\text { Negative } \\
\text { control } \\
\text { (distilled water) }\end{array}$} \\
\hline & I & II & III & I & $\|$ & III & I & II & III & I & II & III & 1 & II & III & I & \| & III \\
\hline S. mutans & - & - & - & - & - & - & - & - & - & - & - & - & 30 & 32 & 28 & - & - & - \\
\hline S. aureus & - & - & - & - & - & - & - & - & - & - & - & - & 12 & 13 & 12 & - & - & - \\
\hline E. faecalis & - & - & - & - & - & - & - & - & - & - & - & - & 13 & 12 & 20 & - & - & - \\
\hline S. pyogenes & - & - & - & _- & - & - & - & - & - & - & - & _- & 16 & 14 & 13 & - & - & - \\
\hline
\end{tabular}

The table shows the diameter of inhibition zones of different concentrations ( $16 \mathrm{mg} / \mathrm{ml}, 8 \mathrm{mg} / \mathrm{ml}, 6 \mathrm{mg} / \mathrm{ml}$, and $2 \mathrm{mg} / \mathrm{ml}$ ) of $A$. denudata extract against selected Gram-positive oral pathogen (S. mutans, S. aureus, E. faecalis, and S. pyogenes). A. denudate: Alocasia denudate, S. mutans: Streptococcus mutans, S. aureus: Staphylococcus aureus, E. faecalis: Enterococcus faecalis, S. pyogenes: Streptococcus pyogenes

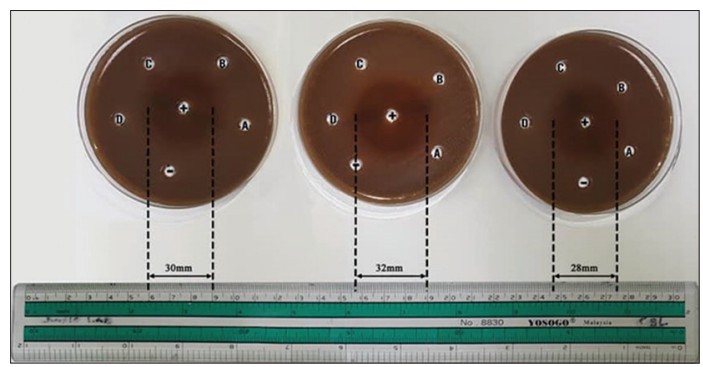

FIGURE 1. Zone of inhibition of Streptococcus mutans. The picture shows the agar well diffusion test of $S$. mutans. (A) Sixteen milligrams/milliliter of Alocasia denudata extract, (B) $8 \mathrm{mg} / \mathrm{ml}$ of A. denudata extract, (C) $4 \mathrm{mg} / \mathrm{ml}$ of $A$. denudata extract, (D) $2 \mathrm{mg} / \mathrm{ml}$ of $A$. denudata extract, $(+)$ ampicillin $20 \mu \mathrm{g} / \mathrm{ml},(-)$ distilled water.

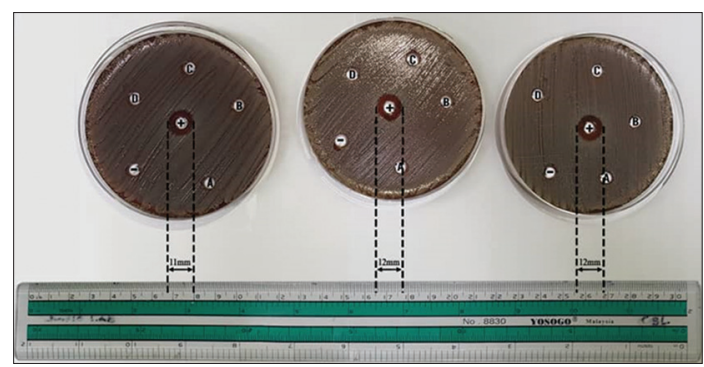

FIGURE 2. Zone of inhibition of Staphylococcus aureus. Picture shows agar well diffusion test of $S$. aureus. (A) Sixteen milligrams/ milliliter of Alocasia denudata extract, (B) $8 \mathrm{mg} / \mathrm{ml}$ of $A$. denudata extract, (C) $4 \mathrm{mg} / \mathrm{ml}$ of $A$. denudata extract, (D) $2 \mathrm{mg} / \mathrm{ml}$ of A. denudata extract, $(+)$ ampicillin $500 \mu \mathrm{g} / \mathrm{ml},(-)$ distilled water.

\section{GC-MS of $A$. denudata extract}

Through GC-MS, 35 individual compounds were identified. The comparison of mass spectra for the constituents, with references from the NIST library,

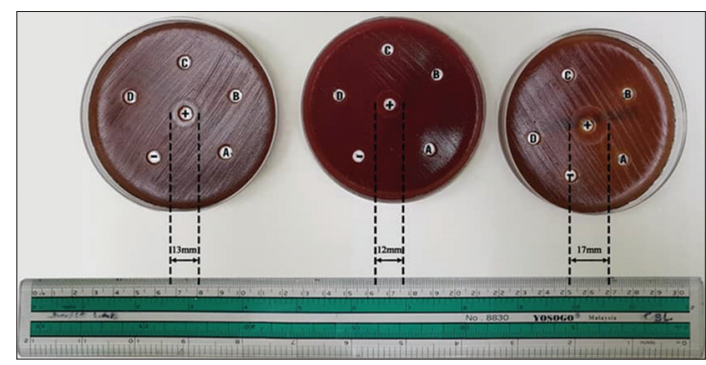

FIGURE 3. Zone of inhibition of Enterococcus faecalis. The picture shows the agar well diffusion test of $E$. faecalis. (A) Sixteen milligrams/milliliter of Alocasia denudata extract, (B) $8 \mathrm{mg} / \mathrm{ml}$ of A. denudata extract, (C) $4 \mathrm{mg} / \mathrm{ml}$ of $A$. denudata extract, (D) $2 \mathrm{mg} / \mathrm{ml}$ of $A$. denudata extract, $(+)$ ampicillin $20 \mu \mathrm{g} / \mathrm{ml},(-)$ distilled water.

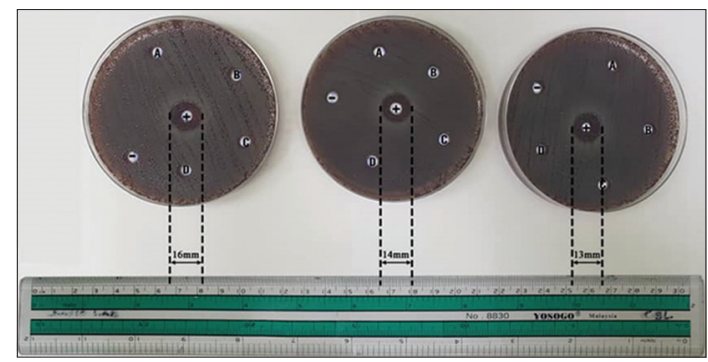

FIGURE 4. Zone of inhibition of Streptococcus pyogenes. The picture shows the agar well diffusion test of $S$. pyogenes. (A) Sixteen milligrams/milliliter of Alocasia denudata extract, (B) $8 \mathrm{mg} / \mathrm{ml}$ of $A$. denudata extract, (C) $4 \mathrm{mg} / \mathrm{ml}$ of $A$. denudata extract, (D) $2 \mathrm{mg} / \mathrm{ml}$ of $A$. denudata extract, (+) ampicillin $20 \mu \mathrm{g} / \mathrm{ml}$, $(-)$ distilled water.

steroid, carbohydrates, and carboxylic acid was characterized and identified, as depicted in Table 4. From the compounds identified, the major compound is carbohydrate having a composition of sucrose 
TABLE 4. Phytochemical analysis. Chemical compound of $A$. denudata extract

\begin{tabular}{lc}
\hline Compound name & Percentage of total ion chromatogram \\
\hline Steroid & 1.29 \\
Beta.-Sitosterol trimethylsilyl ether & 0.70 \\
Stigmasterol trimethylsilyl ether & 0.31 \\
Campesterol trimethylsilyl & 0.28 \\
Carbohydrates & 17.23 \\
Sucrose trimethylsilyl & 7.79 \\
Beta.-D-Galactofuranose,1,2,3,5,6-pentakis-O-trimethylsilyl)- & 2.49 \\
Alpha.-D-Glucopyranoside,1,3,4,6-Tetrakis-O-(Trimethylsilyl)- & 1.93 \\
Fucose Per trimethylsilyl & 0.78 \\
Per trimethylsilyl derivative of 1,4-Anhydroglucitol & 0.65 \\
Glucopyranose,1,2,3,4,6-pentakis-O-(trimethylsilyl)- & 0.59 \\
3,7-Dioxa-2,8-disilanonane,2,2,8,8-tetramethyl-5-(trimethylsilyl)oxy) & 0.55 \\
D-Xylopyranose, 1,2,3,4-tetrakis-O-(trimethylsilyl)- & 0.38 \\
Levoglucosan, tris(trimethylsilyl)- & 0.37 \\
Trimethylsilyl ether of glycerol & 0.29 \\
Maltose-Octatms & 0.28 \\
Nigerose Meox1 trimethylsilyl & 0.27 \\
Raffinose trimethylsilyl & 0.26 \\
Erythritol per trimethylsilyl & 0.18 \\
Alpha.-D-Glucopyranoside,1,3,4,6-Tetrakis-O-(Trimethylsilyl)- & 0.15 \\
Glucopyranose,1,2,3,4,6-pentakis-O-(trimethylsilyl)- & 0.11 \\
Melibiose 8 trimethylsilyl & 0.10 \\
D-Glucopyranose,4-O-(2,3,4,6-Tetrakis-O-(Trimethylsilyl)- & 0.08 \\
Melibiose, octakis(trimethylsilyl)- & 0.05 \\
D-Xylose, tetrakis(trimethylsilyl)- & 0.05 \\
Carboxylic acid & 0.59 \\
Malic acid trimethylsilyl & 0.24 \\
Butanedioic acid, bis(trimethylsilyl) ester & 0.18 \\
Tetronic acid, Tetrakis-O-(Trimethylsilyl)- & 0.17 \\
\hline A. &
\end{tabular}

A. denudate: Alocasia denudate

trimethylsilyl (7.79\%), Beta. -D-Galactopyranose, 1,2,3,5,6-pentakis-O-(trimethylsilyl) (2.49\%), and Alpha. -D-Glucopyranoside, 1,3,4,6-Tetrakis-O(Trimethylsilyl) (1.93\%). The medicinal activity of the plant is presented in Table 5. Among the compounds identified, six compounds were reported to have anti-inflammatory and antioxidant activity, whereas one was showing antimicrobial properties.

\section{DISCUSSION}

\section{The yield of $A$. denudata extract}

Phytochemicals of the medicinal plants can be obtained from an extraction process that has few steps such as milling, grinding, homogenization, and extraction. It is believed that extraction is the main step for recovering and isolating the phytochemicals from plant materials. There are a few factors that affect the extraction efficiency, which is the chemical nature of phytochemicals, the extraction methods used, the sample particle size, the solvent used, and the presence of interference (14). Besides, the type of solvent used will affect the yield of extraction in terms of varying polarity, $\mathrm{pH}$, temperature, extraction time, solvent, and composition of a sample. In this experiment, $A$. denudata extract was obtained using $80 \%$ ethanol. However, among parameters such as solvent types, solvent strength, 


\begin{tabular}{lll}
\hline \multicolumn{2}{l}{ TABLE 5. Phytochemical properties of phytocompound } & \\
\hline Num. & Compound & Biological activity \\
\hline I & Alpha.-D-Glucopyranoside,1,3,4,6-Tetrakis-O-(Trimethylsilyl)- & Antioxidant (28) \\
II & Stigmasterol trimethylsilyl ether & $\begin{array}{l}\text { Anti-inflammatory, inhibits tumor promotion, anti-HIV } \\
\text { reverse transcriptase (28) }\end{array}$ \\
III & Butanedioic acid, bis(trimethylsilyl) ester & Antioxidant, antiradical (29) \\
IV & Propanoic acid,2,3-bis(trimethylsilyl)oxy)-, trimethylsilyl ester & Antioxidant, Antiproliferative (29) \\
V & Alpha.-Tocopherol (Vitamin E), trimethylsilyl derivative & Antioxidant (29) \\
VI & Beta.-Sitosterol trimethylsilyl ether & Antibacterial (25) \\
\hline
\end{tabular}

extraction time, agitation speed, sample-solvent ratio, and temperature investigated using factorial design experiment; solvent strength, which is $70 \%$ ethanol, is the most influential factors in Curcuma longa extraction (15). About 70\% concentration of ethanol was used as a soaking solvent since they are the most preferred solvent for phenolic extraction from the plant (16). As our sample might contain both polar and non-polar components, the use of a mixer of polar/non-polar solvent gave us the best output. Ethanol is a polar solvent that can be used to extract sugar, amino acids, and glycoside from the sample (17). Secondary metabolites (terpenes, phenolic compounds, and alkaloid) from the plant extracts are polar compounds that are responsible and good in displaying antibacterial activity (18).

Compounds present in the solvents may contribute to a higher yield. Choosing an appropriate solvent is important in the process of obtaining the extract with a desirable content of bioactive compounds. In general, phenolic compounds are soluble in alcohols such as ethanol, whereas less polar solvent is used to extract the less polar compound. Aqueous methanol can be used as one of the solvents to produce the best results in the future (16).

However, the potential antimicrobial activity of A. denudata cannot be determined by the percentage of yield alone. GCMS is one of the techniques used to determine the compound present in the extraction.

\section{Agar well diffusion test}

The search for antimicrobials from natural sources has gained extensive attention and effort to identify the active compounds that can substitute the synthetic one as an antimicrobial agent. Phytochemicals that are present in plants were then used as a prototype to develop less toxic and more effective medicines in controlling the growth of microorganism (19). At present, numerous studies have been conducted using various extracts of the plant, screening of antimicrobial activity, as well as for the discovery of new antimicrobial compounds. Thus, medicinal plants are finding their way into pharmaceuticals, nutraceuticals, and food supplements.

Agar well diffusion test offers a means of qualitative measurement based on the diameter of the inhibition zone for early screening of antimicrobial agents in the natural product. In this study, different concentrations of ethanolic extract of $A$. denudate were evaluated for the screening of antimicrobial activity against a selected oral pathogen which is Grampositive bacteria using agar well diffusion methods. This preliminary study showed that there was no antimicrobial activity by different concentrations of extract toward four pathogens which are $S$. mutans, $S$. aureus, E. faecalis, and $S$. pyogenes. The ethanolic extract did not show any antibacterial activity and this could be due to low phenolic content extracted by the solution (20). According to the study by Dabur et al. (21) who investigated the antibacterial ability of the ethanolic extract of Achyranthes bidentata Blume effectively inhibited Bacillus subtilis, Salmonella typhi, and Klebsiella pneumoniae, but was less effective against Pseudomonas species and $S$. aureus. Considering other studies that the water extract of Rauvolfia tetraphylla and Physalis minima leaves could inhibit B. subtilis and $S$. aureus, our $80 \%$ mixer of extra water (polar) and alcohol (none/ less polar) help to extract maximum compounds in A. denudate (22).

Furthermore, the absence of antimicrobial activity in this study might be due to the absence of secondary metabolites such as alkaloids, flavonoids, 
tannins, and terpenoids as revealed from the GCMS results. The extent of permeability possesses by a particular organism and the chemical nature of the antimicrobial agent affects the mechanism of the antimicrobial action. This agent needs to enter the bacteria cells by transmembrane pores or by passive diffusion for a lipophilic compound to establish the antimicrobial action. Besides, the absence of antimicrobial properties might be due to some chemical composition in the plant extract which is responsible for the antimicrobial activity required to enter the cytoplasm of the bacteria cell to utilize its inhibitory action (23).

\section{GC-MS}

From our preliminary GC-MS analysis, only 35 compounds were identified $(19.11 \%)$ in $A$. denudata extract, and only one compound is found to be steroid (Beta-Sitosterol trimethylsilyl ether) which is known to have antimicrobial property. Other phytochemicals that cannot be extracted in this $A$. denudata extract such as phenols, flavonoids, and alkaloids had been proven to show the antimicrobial effect that might be attributed to the evaporation of the active components, photooxidation, or insufficient amount of the active component (24). According to Doğan et al., beta-sitosterol trimethylsilyl ether inhibits the growth of $S$. aureus at the concentration of $32 \mu \mathrm{g} / \mathrm{ml}$ (25). However, our screening on the inhibition zone toward the selected oral pathogen did not show any antimicrobial property although the concentration used was higher than $32 \mu \mathrm{g} / \mathrm{ml}$. The discrepancy might be due to antimicrobial compound degradation before susceptibility testing, high molecular weight, and the resistance of oral bacteria toward this plant (26) and it could be due to low percentage of total ion of Beta-Sitosterol trimethylsilyl ether in this plant even it is used in higher concentration than $32 \mu \mathrm{g} / \mathrm{ml}$. The low percentage of yield obtained may be due to the decrease in solubility of the phytochemical in the solvent (27) which requires optimization of ethanol percentage $(28,29)$.

\section{CONCLUSION}

The extract of $A$. denudata contains an antimicrobial compound with no antimicrobial activity toward selected Gram-positive oral pathogens.

\section{ACKNOWLEDGMENT}

The authors would like to thank Universiti Sains Malaysia for providing financial support under Short Term Grant (304/PPSG/61313196).

\section{REFERENCES}

1. Yaacob M, Kadir AA, Hasan Z. Tumbuhan Ubatan Popular Malaysia. Kuala Lumpur: Institut Penyelidikan dan Kemajuan Pertanian Malaysia; 2009. p. 35.

2. Roy S, Choudhury DS. In vitro antibacterial activity of Alocasia decipiens Schott. Asian J Pharm Clin Res 2013;6(2):120-2.

3. Wei P, Zhiyu C, Xu T, Xiangwei Z. Antitumor effect and apoptosis induction of Alocasia cucullata (Lour.) G. Don in human gastric cancer cells in vitro and in vivo. BMC Complement Altern Med 2015;15:33.

https://doi.org/10.1186/s12906-015-0554-2.

4. Islam MK, Mahmud I, Saha S, Sarker AB, Mondal H, Monjur-Al-Hossain A, et al. Preliminary pharmacological evaluation of Alocasia indica Schott tuber. J Integr Med 2013;11(5):343-51.

https://doi.org/10.3736/jintegrmed2013045.

5. Jawaid T, Argal S, Kamal M. Antidiabetic and antihyperlipidemic effects of the ethanolic extract of Alocasia indica Rhizomes in high fat diet/streptozotocin and streptozotocin/nicotinamide-induced Type 2 diabetic rats. Asian J Pharm Clin Res 2015;8(6):58-62.

https://doi.org/10.22159/ajpcr.2019.v12i11.35421.

6. Payum T, Das A, Shankar R. Nutraceutical folk food plants used among indigenous people of east Siang district of Arunachal Pradesh, India. Am J PharmTech Res 2015;4(4):696-704.

7. Latif MA, Zaki MZ, Leng TM, Rahman NH, Arshad SA, Hamid A. Alocasia denudata Engler treatment enhance open wound healing activities in Wistar rats skin. J Ethnopharmacol 2015;176:258-67.

https://doi.org/10.1016/j.jep.2015.10.036.

8. Nagi R. Role of medicinal herbs in management of oral diseases a review. J Dent Med Sci 2015;14(8):40-4.

9. Carmen C, Veronica L, Mariana CC. Pesticides and antimicrobial resistance: From environmental compartments to animal and human infections. In: New Pesticide and Soil Sensors. Cambridge, Massachusetts: Academic Press; 2017. p. 373-92.

10. Nascimento GG, Locatelli J, Freitas PC, Silva GL. Antibacterial activity of plant extracts and phytochemicals on antibiotic-resistant bacteria. Braz $J$ Microbiol 2000;31(4):247-56.

https://doi.org/10.1590/s1517-83822000000400003.

11. Ibeh IN. General and Reproductive Toxicology. Nigeria: United Press; 1998. p. 68.

12. Othman L, Sleiman A, Abdel-Massih RM. Antimicrobial activity of polyphenols and alkaloids in Middle Eastern plants. Front Microbiol 2019;10:911. https://doi.org/10.3389/fmicb.2019.00911.

13. Azam A, Ahmed AS, Oves M, Khan MS, Habib SS, Memic A. Antimicrobial activity of metal oxide nanoparticles against Gram-positive and Gramnegative bacteria: A comparative study. Int J Nanomed 2012;7:6003-9.

https://doi.org/10.2147/ijn.s35347.

14. Stalikas $C D$. Extraction, separation, and detection methods for phenolic acids and flavonoids. J Sep Sci 2007;30(18):3268-95.

https://doi.org/10.1002/jssc.200700261.

15. Paulucci VP, Couto RO, Teixeira CC, Freitas LA. Optimization of the extraction of curcumin from Curcuma longa Rhizomes. Braz J Pharmacogn 2013;23:94-100.

https://doi.org/10.1590/s0102-695x2012005000117. 
16. Apak R, Güçlü K, Demirata B, Özyürek M, Çelik S, Bektaşoğlu B, et al. Comparative evaluation of various total antioxidant capacity assays applied to phenolic compounds with the CUPRAC assay. Molecules 2007;12:1496-547.

https://doi.org/10.3390/12071496.

17. Houghton PJ, Raman A. Laboratory Handbook for the Fractionation of Natural Extracts. London: Springer-Science Business Media; 2013.

18. Agostini-Costa TD, Viera RF, Bizzo HR, Silveira D, Gimenes MA. Secondary metabolites. In: Chromatography and its Applications. Vol. 8. Cambridge: Cambridge University Press; 2012. p. 131-42.

19. Kelmanson JR, Jager AK, Staden JV. Zulu medicinal plants with antibacterial activity. J Ethnopharmacol 2000;69(3):241-6. https://doi.org/10.1016/s0378-8741(99)00147-6.

20. González-Montelongo R, Lobo MG, González M. Antioxidant activity in banana peel extracts: Testing extraction conditions and related bioactive compounds. Food Chem 2010;119(3):1030-9.

https://doi.org/10.1016/j.foodchem.2009.08.012.

21. Dabur R, Gupta A, Mandal TK, Singh DD, Bajpai V, Gurav AM, et al. Antimicrobial activity of some Indian medicinal plants. Afr J Tradit Complement Altern Med 2007;4:313-8.

https://doi.org/10.4314/ajtcam.v4i3.31225.

22. Shariff N, Sudarshana MS, Umesha S, Hariprasad P. Antimicrobial activity of Rauvolfia tetraphylla and Physalis minima leaf and callus extracts. Afr J Biotechnol 2006;5:946-50.

23. Wax RG, Lewis K, Salyers AA, Taber H. Bacterial Resistance to
Antimicrobials. Boca Raton, Florida: CRC Press; 2007. https://doi.org/10.1201/9781420008753.

24. Masoko P, Picard J, Eloff J. Antifungal activities of six South African Terminalia species (Combretaceae). J Ethnopharmacol 2005;99:301-8. https://doi.org/10.1016/j.jep.2005.01.061.

25. Doğan A, Otlu S, Çelebi Ö, Kiliçle PA, Sağlam AG, Doğan AN, et al. An investigation of antibacterial effects of steroids. Turk J Vet Anim Sci 2017;41:302-5

https://doi.org/10.3906/vet-1510-24.

26. Jiang L. Comparison of Disk Diffusion, Agar Dilution, and Broth Microdilution for Antimicrobial Susceptibility Testing of Five Chitosans. Louisiana: Louisiana State University and Mechanical College, Master's Theses 2011. p. 727. Available from: https://www.pdfs.semanticscholar. org/6fae/988f3c26f7d54ea89a58bce6d2c9a6ca7955.pdf. [Last accessed on 2019 Jan 03].

27. Ibrahim R, Abu Bakar EM, Misau M, Bala GL. Percentage yield and acute toxicity of the plant extracts of Ceiba pentandra grown in Bauchi State, North Eastern Nigeria. J Pharmacogn Phytochem 2017;6(5):1777-9.

28. Hsu FL, Huang WJ, Wu TH, Lee MH, Chen LC, Lu HJ, et al. Evaluation of antioxidant and free radical scavenging capacities of polyphenolics from pods of Caesalpinia pulcherrima. Int J Mol Sci 2012;13(5):6073-88. https://doi.org/10.3390/ijms13056073.

29. Handayani S, Yuwono SS, Suprayitno E. Isolation and identification structure antioxidant active compounds of ethyl acetate fraction hypokotil Bruguiera gymnorhiza (L) Lamk. Int J ChemTech Res 2015;8(4):1858-67. 